\title{
Climatic factors as quality determinant of essential oils and phenolics in Rosmarinus officinalis L. (Lamiales Lamiaceae) collected from three geographic areas in Algeria
}

\author{
Ouroud Fellah', Samir Hameurlaine ${ }^{2}$, Naziha Bourenane', Noureddine Gherraf ${ }^{2}$, Amar Zellagui ${ }^{3}$, Abdenabi \\ Abidi $^{4}$, Ali Tahar', Muhammed Altun ${ }^{5}$, Ibrahim Demirtas $^{5}$ \& Ayse Sahin Yaglioglu ${ }^{5}$ \\ ${ }^{1}$ Faculty of Sciences, Department of Natural and Life Sciences, University of Badji Mokhtar Annaba, 23000, Algeria \\ ${ }^{2}$ Laboratory of Natural Resources and Management of Sensitive Environments, Larbi ben M'hidi University, Oum El Bouaghi, \\ Algeria; e-mail: ngherraf@yahoo.com \\ ${ }^{3}$ Laboratory of Biomolecules and Plant Breeding, Faculty of Exact Sciences and Life and Nature Sciences, University of Larbi \\ Ben M'hidi Oum El Bouaghi, Algeria \\ ${ }^{4}$ Department of Process Engineering, Badji Mokhtar University, Annaba 23000, Algeria \\ ${ }^{5}$ Laboratory of Plant Research, Department of Chemistry, Faculty of Science, Gaziosmanpaşa University, Department of Chemistry \\ Uluyazi Campus, Cankiri Karatekin University, Cankiri, Turkey \\ "Corresponding author, e-mail: chelox_8224@yahoo.com
}

ABSTRACT

KEY WORDS
The present work was aimed to evaluate the effect of the climatic factors on quality and quantity of essential oils and phenolic compounds of the aerial parts of Rosmarinus officinalis L. (Lamiales Lamiaceae) collected from three different geographic origins in Algeria (humid, semi arid, and arid). Gas-Chromatography/Mass-Spectroscopy analysis of essential oils revealed important disparities, both quantitatively and qualitatively. $\alpha$-pinene and camphor as major components were found to range from 16.78 to $40.95 \%$ and from 11.24 to $36.72 \%$, respectively. The assessment of total phenolics in water and ethyl acetate extracts of the three samples displayed a content ranging from 58.26 to $114.10 \mathrm{mg}$ GAE (gallic acid equivalent)/g of water extracts and from 73.75 to $167.91 \mathrm{mg} \mathrm{GAE} / \mathrm{g}$ of ethyl acetate extracts. The flavonoids content was found to vary from 14.63 to $28.86 \mathrm{mg}$ QE (quercetin equivalent)/g of water extracts and from 66.2 to $93.1 \mathrm{mg}$ QE/g of ethyl acetate extracts. Moreover, the HPLC analysis of phenolics revealed the presence of many compounds amongst which Hesperidin and Rosmarinic acid have relatively high contents in both extracts and in the three sites.

Received 01.05.2018; accepted 11.07.2018; printed 30.09.2018; published online 05.10.2018

\section{INTRODUCTION}

Plant secondary metabolites are considered as the major source of supply for pharmaceuticals, food additives, perfumes, savors, and other key compounds in chemistry and bio-chemistry widely used in everyday life. The role of secondary metabolites continues to be a contentious subject. Unlike the primary metabolites, which govern all fundamental physiological processes necessary to the growth and development of plants, secondary metabolites are mandatory in the survival of the 
plant in its environment. They constitute an essential part of the armamentaria used by plants in the fight to survive and proliferate. Their role may centre on defense of the producer against predators (herbivores), pathogens, or competitors, on assistance to pollination or seed dispersal, or on protection against or adaptation to extrinsic abiotic factors and in overcoming stress conditions, or combinations of these functions (Ramakrishna \& Ravishankar; 2011; Rhodes, 1994; Borges et al., 2013). Environmental factors such as soil composition, temperature, latitude, humidity, light intensity, rainfall, evaporation, minerals, and $\mathrm{CO}_{2}$ have a fundamental impact on the growth of a plant and accumulation of secondary metabolites and, hence, influence directly the quality of the plant for medicinal application and therapeutic value. Plants have the ability to overcome biological, physical, chemical, and ecological stresses by acclimatizing the buildup of secondary metabolites. Therefore, researches on the impact of ecological factors on the accretion of secondary metabolites in medicinal plants become a hot subject of prime concern (Gobbo-Neto \& Lopes, 2007; Guo et al., 2013; Hanif et al., 2018).

Algeria is characterized by a mild Mediterranean climate along the coast, a transitional climate in the northern hills and mountains, a little more continental and moderately rainy, and finally the desert climate of the vast area occupied by the Sahara. The landscapes of Algeria, from desert, mountains, valley, and plateaus to basins support thousands of floral species, many of which are endemic to the country. This striking biodiversity led us to carry out this investigation on the effect of climatic conditions on the content of essential oils and phenolics in both water and ethyl acetate extracts of a widely used medicinal plant, Rosmarinus officinalis L. (Lamiales Lamiaceae), taken in three distinguished geographic locations (arid, semi arid, and humid).

Rosmarinus officinalis is a popular fragrant and medicinal plant. Many authors consider this species as the most used folk species worldwide because its volatile components and phenolics are continuously reported to possess important biological assets. Depending on what has been stated in literature, its secondary metabolites may vary according to the harvesting time, extraction technique, climate conditions, geographic origins, phenological stages, etc. The plant is traditionally used as an antispasmodic in renal colic and dysmenorrhoea and in relieving respiratory disorders. It has also been used as an analgesic, antirheumatic, carminative, cholagogue, diuretic, expectorant, antiepileptic, and for human fertility. Other uses are as a general tonic in case of excessive physical or intellectual works and in heart diseases. Externally, it is a rubefacient, and a stimulant for the growth of hair and treatment of eczema of the scalp. Moreover, it was reported to relax smooth muscles of trachea and intestine. The most important constituents of rosemary are caffeic acid and its derivatives, such as rosmarinic acid (Tai et al., 2012; Rozman \& Jersek, 2009; Singh \& Guleria, 2013; Bajalan et al., 2017; AI-Sereiti et al., 1999).

\section{MATERIALS AND METHODS}

\section{Soil and climatic data}

The geographic areas covered in this study are Oum El Bouaghi (site 1: semi arid), el Taref (site 2: humid), and Ouargla (site 3: arid). The climate data during 2015 were obtained from the available climate database of the National office of Meteorology, Algeria (Tables 1-3).

\section{Plant material}

The aerial parts of $R$. officinalis were collected from Oum El Bouaghi (site 1: semi arid), El Taref (site 2: humid), and Ouargla (site 3: arid). The plants were identified by Pr. A. Zellagui, Oum El Bouaghi University, Algeria. Voucher specimens (RO1, RO2, RO3) of the three sites respectively were deposited in the Laboratory of Natural Resources and Management of Sensitive Environments, University of Oum El Bouaghi, Algeria

\section{Essential oil extraction}

Hydrodistillation is used in the extraction of essential oil. This is the simplest and usually the cheapest distillation procedure. It works better for powders and tough materials. In this method, the plant material is heated, by placing it in water, which is brought to the boil. The heat causes the 
cell structure of the plant to burst and break down, thus releasing the essential oils. The essential oil molecules and steam are carried along a pipe and conducted through a refrigerator, where they return to the liquid form and collected in a holder. The rising liquid is a mixture of oil and water, and because essential oils are not water soluble, they can be easily separated from the water and siphoned off. In our case, $300 \mathrm{~g}$ of each plant sample was ground and subjected to hydrodistillation for 3 hours in a Clevenger type apparatus.

\section{Water extract}

$500 \mathrm{~mL}$ of distilled water were added to $100 \mathrm{~g}$ of finely ground dry plant material for each sample. After 60 minutes, the aqueous extract was filtered and dried under vacuum, weighed, and prepared for HPLC analysis.

\section{Ethyl acetate extract}

$100 \mathrm{~g}$ of dry plant material of each sample was subjected to overnight extraction using ethyl acetate. After separation, the organic phase was evaporated and the crude extract was weighed and prepared for further analysis.

\section{Gas Chromatography/Mass Spectrometry (GC/MS) Analysis}

GC/MS analyses were obtained on Perkin Elmer mass spectrometer with built-in auto sampler using BPX-20 column $(30 \mathrm{~m} \times 0.25 \mathrm{~mm} \times 0.25$ $\mu \mathrm{m}$ film). For GC/MS detection, an electron ionization system, ionization energy of $70 \mathrm{eV}$, was used. Helium was the carrier gas, at a flow rate of $1.3 \mathrm{~mL} / \mathrm{min}$. The column temperature was operated under the same conditions as described above.

Identification of the individual components was based on (a) comparison of their GC retention indices (RI) with those of authentic compounds or literature data and (b) computer matching with a mass spectral library and commercial libraries (WILLEY and NIST database/ChemStation data system).

\section{Determination of total phenolic contents}

The concentration of phenolics in plant extracts was determined using spectrophotometric method
(Singleton et al., 1999). The methanol solution of the extract at the concentration of $1 \mathrm{mg} / \mathrm{mL}$ was used in the analysis. The reaction mixture was prepared by mixing $0.5 \mathrm{~mL}$ of methanol solution of extract, $2.5 \mathrm{~mL}$ of $10 \%$ Folin-Ciocalteu's reagent dissolved in water and $2.5 \mathrm{~mL} 7.5 \% \mathrm{NaHCO} 3$. Blank was concomitantly prepared, containing 0.5 $\mathrm{mL}$ methanol. $2.5 \mathrm{~mL} \mathrm{10 \%}$ Folin-Ciocalteu's reagent dissolved in water and $2.5 \mathrm{~mL}$ of $7.5 \%$ of $\mathrm{NaHCO} 3$. The samples were thereafter incubated in a thermostat at $45^{\circ} \mathrm{C}$ for $45 \mathrm{~min}$. The absorbance was determined using spectrophotometer at $\lambda \max$ $=765 \mathrm{~nm}$. The samples were prepared in triplicate for each analysis and the mean value of absorbance was obtained. The same procedure was repeated for the standard solution of gallic acid and the calibration line was constructed. Based on the meas-

\begin{tabular}{|c|c|c|c|}
\hline parameters & $\begin{array}{c}\text { Oum El Bouaghi } \\
\text { (site 1) }\end{array}$ & El Taref (site 2) & Ouargla( site 3) \\
\hline $\begin{array}{c}\text { Latitude and } \\
\text { Longitude }\end{array}$ & $\begin{array}{c}35^{\circ} 52^{\prime} 31^{\prime \prime} \mathrm{N}, \\
7^{\circ} 06^{\prime} 48^{\prime \prime} \mathrm{E}\end{array}$ & $\begin{array}{c}36^{\circ} 46^{\prime} 01^{\prime \prime} \mathrm{N}, \\
8^{\circ} 18^{\prime} 49^{\prime \prime} \mathrm{E}\end{array}$ & $\begin{array}{c}31^{\circ} 56^{\prime} 57^{\prime \prime} \mathrm{N}, \\
5^{\circ} 19^{\prime} 30^{\prime \prime} \mathrm{E}\end{array}$ \\
\hline $\begin{array}{c}\text { Altitude (meters } \\
\text { above sea level })\end{array}$ & 925 & 24 & 138 \\
\hline Clay \% & 21.93 & 35.45 & 03.27 \\
\hline Silt \% & 38.42 & 16.74 & 0.3 \\
\hline Sand \% & 39.6 & 47.8 & 96.44 \\
\hline Texture & $10 a m$ & $5 i l t y$ clay & silty \\
\hline $\begin{array}{c}\mathrm{EC} \mathrm{(electric} \\
\text { conductivity) }\end{array}$ & 0.37 & 0.37 & 0.30 \\
\hline pH & 7.22 & 7.47 & 7.86 \\
\hline CaCO3 T \% & 19.78 & 0.86 & 1.29 \\
\hline CaCO3 $\%$ & 14.38 & 0.00 & 0.00 \\
\hline $\begin{array}{c}\text { OM (organic } \\
\text { matter) }\end{array}$ & 5.07 & 1.69 & 2.53 \\
\hline
\end{tabular}

Table1. Geographical and soil characteristics of different collection sites.

\begin{tabular}{|c|c|}
\hline Analysis parameter & Methods \\
\hline Particle size (\%), & pipette method ROBINSON ISO, 11277 \\
\hline pH Rapport $1 / 2.5$ at $25^{\circ} \mathrm{C}$ & Soil referential; 1995 \\
\hline $\mathrm{EC}(\mathrm{dS} / \mathrm{m})$ rapport $1 / 5$ at $25^{\circ} \mathrm{c}$ & FA0, 1985 \\
\hline $\mathrm{CaCO}_{3} \mathrm{~T}(\%)$ & G.E.P.P.A \\
\hline OM $(\%)$ & Brochure OLIB \\
\hline
\end{tabular}

Table 2. Analyses Methods. 
ured absorbance, the concentration of phenolics was read $(\mathrm{mg} / \mathrm{mL})$ from the calibration line; then the content of phenolics in extracts was expressed in terms of gallic acid equivalent ( $\mathrm{mg}$ of GAE/g of extract).

\section{Determination of total flavonoids}

The content of flavonoids in the examined plant extracts was determined using spectroscopic method (Quettier et al., 2000). The sample contained $1 \mathrm{~mL}$ of methanol solution of the extract at a concentration of $1 \mathrm{mg} / \mathrm{mL}$ and $1 \mathrm{~mL}$ of $2 \% \mathrm{AlCl} 3$ solution dissolved in methanol. The samples were incubated for an hour at room temperature. The absorbance was determined using spectrophotometer at $\lambda \max =430 \mathrm{~nm}$. The samples were prepared in triplicate for each analysis and the mean value of absorbance was obtained. The same procedure was repeated for the standard solution of quercetin and the calibration line was construed. Based on the measured absorbance, the concentration of flavonoids was read $(\mathrm{mg} / \mathrm{mL})$ on the calibration line; then, the content of flavonoids in extracts was expressed in terms of quercetin equivalent ( $\mathrm{mg}$ of $\mathrm{QE} / \mathrm{g}$ of extract).

\section{HPLC-TOF/MS analysis}

Phenolic content of the plant extracts was determined using Agilent Technology of 1260 Infinity. HPLC System was coupled with 6210 Time of Flight (TOF) LC/MS detector and ZORBAX SBC18 $(4.6 \times 100 \mathrm{~mm}, 3.5 \mu \mathrm{m})$ column. Mobile phases $\mathrm{A}$ and $\mathrm{B}$ were ultra-pure water with $0.1 \%$ formic acid and acetonitrile respectively. Flow rate was $0.6 \mathrm{mLmn}-1$ and column temperature was $35^{\circ} \mathrm{C}$. Injection volume was $10 \mu \mathrm{L}$. The solvent program was as follow: $0-1 \min 10 \% \mathrm{~B} ; 1-20 \min 50 \% \mathrm{~B}$; 20-23 min $80 \% \mathrm{~B}$; $23-30$ min $10 \% \mathrm{~B}$. Ionization mode of HPLC-TOF/MS instrument was negative and operated with a nitrogen gas temperature of $325^{\circ} \mathrm{C}$. Nitrogen gas flow was $10.0 \mathrm{~L}$ min-1, nebulizer of $40 \mathrm{psi}$, capillary voltage of $4000 \mathrm{~V}$, and finally, fragmentor voltage of $175 \mathrm{~V}$. For sample analysis, dried crude extracts (200 ppm) were dissolved in methanol at room temperature. Samples were filtered passing through a PTFE $(0.45 \mu \mathrm{m})$ filter by an injector to remove particulates.

\section{RESULTS AND DISCUSSION}

\section{Essential oils}

The GC-MS fingerprints of essential oils of the three samples were established. Table 4 shows the essential oil composition of $R$. officinalis from the three precited sites, $\mathrm{RO} 1, \mathrm{RO} 2$, and $\mathrm{RO} 3$, respectively.

16 compounds were identified in sample RO1, 21 in sample RO2, and 21 in sample RO3, making up a total of 25 different compounds in all samples representing more than $99 \%$ of the total oils. All the identified components have been reported previously. The constituents: $\alpha$-pinene, camphene, limonene, eucalyptol, linalool, camphor, isoborneol, and verbenone account more than $82 \%$ of weight in the three samples.

The major compounds in RO1 are $\alpha$-pinene (40.95\%), verbenone (11.90), camphor (11.24\%), camphene $(8.08 \%)$, limonene $(5.49 \%)$, and isborneol (3.96\%). RO2, instead, involves a quite different quantitative order of the major components, namely camphor (19.26\%), $\alpha$-pinene $(16.78 \%)$, isoborneol $(12.29 \%)$, verbenone $(12.19 \%)$, eucalyptol (11.88\%), limonene (3.52\%). Sample RO3, in turn, contains distinguished chemotypes explicitly: camphor $(36.72 \%), \alpha$-pinene $(17.16 \%)$, eucalyptol (13.88\%), iso-borneol (7.58\%), camphene (4.92\%), and Verbenone (3.44\%). All major components showed significant discrepancies between samples. There are many reports regarding the variation of rosemary essential oil according to geographic origin. It was reported that camphor (14.3-17.5\%), Eucalyptol (11.0-21.6\%), and $\alpha$ pinene $(10.2-12.5 \%)$ were the major essential oil components in populations growing in Turkey (Gurbuz et al., 2016). Morocco rosemary was found to be rich in Eucalyptol (47.44\%), $\alpha$-pinene $(12.51 \%)$, and camphor $(7.9 \%)$, while $\alpha$-pinene was the major component of rosemary collected in Spain $(24.7 \%)$ and France $(35.80 \%)$ (Chalchat et al., 1993). In Algeria, it was reported that the plant contains Eucalyptol (52.4\%), camphor (12.6\%), and $\beta$-pinene (5.7\%) (Boutekedjiret et al., 1998). Pino reported the composition of rosemary from Cuba to be: camphor (34.80\%), borneol (11.6\%), Eucalyptol (11\%), and $\alpha$-pinene $(8.17 \%)$ (Pino et al., 1998). Balkan Peninsula rosemary was found 


\begin{tabular}{|c|c|c|c|c|c|c|c|c|c|c|c|}
\hline \multirow{2}{*}{ Month } & \multicolumn{3}{|c|}{$\begin{array}{c}\text { Average Mean } \\
\text { Temperature }\end{array}$} & \multicolumn{3}{c}{$\begin{array}{c}\text { Average Humidity, } \\
\text { rate \% }\end{array}$} & \multicolumn{3}{c|}{$\begin{array}{c}\text { Relative precipitation } \\
\text { in mm }\end{array}$} & \multicolumn{2}{c|}{$\begin{array}{c}\text { Relative } \\
\text { Evaporation in } \\
\text { in mm }\end{array}$} \\
\hline & Site 1 & Site 2 & Site 3 & Site 1 & Site 2 & Site 3 & Site 1 & Site 2 & Site 3 & Site 1 & Site 2 \\
\hline Jan & 5.9 & 11.3 & 11.4 & 81 & 85 & 52 & 39 & 124 & 1 & 49 & 27 \\
\hline Feb & 5.7 & 11.8 & 14.2 & 80 & 83 & 56 & 52 & 82 & 24 & 41 & 19 \\
\hline Mar & 9.6 & 13.7 & 17.4 & 71 & 73 & 47 & 22 & 68 & 4 & 86 & 40 \\
\hline Apr & 14.3 & 15.5 & 24.4 & 60 & 74 & 36 & 3 & 53 & 0.0 & 114 & 31 \\
\hline May & 19.1 & 19 & 28.9 & 54 & 70 & 38 & 16 & 39 & 0.0 & 189 & 38 \\
\hline June & 22.4 & 23 & 32.3 & 52 & 68 & 30 & 10 & 16 & 0.0 & 250 & 48 \\
\hline July & 26 & 25.7 & 34.3 & 46 & 63 & 30 & 27 & 3 & 0.0 & 259 & 52 \\
\hline Aug & 25.9 & 26.5 & 36 & 51 & 65 & 38 & 68 & 5 & 0.0 & 208 & 51 \\
\hline Sept & 22.2 & 24.5 & 30.9 & 56 & 67 & 45 & 6 & 37 & 1 & 162 & 41 \\
\hline Oct & 17.4 & 20.2 & 24.8 & 58 & 73 & 45 & 46 & 72 & 0.0 & 184 & 31 \\
\hline Nov & 11.2 & 16 & 17.7 & 77 & 80 & 56 & 44 & 90 & 0.0 & 51 & 19 \\
\hline Dec & 7.8 & 12.4 & 12.5 & 69 & 82 & 54 & 43 & 105 & 0.0 & 48 & 10 \\
\hline average & $\mathbf{1 5 . 6 2}$ & $\mathbf{1 8 . 3 0}$ & $\mathbf{2 3 . 7 3}$ & $\mathbf{6 2 . 9 1}$ & $\mathbf{7 3 . 5 8}$ & $\mathbf{4 3 . 9 1}$ & $\mathbf{3 1 . 3 3 3}$ & $\mathbf{5 7 . 8 3}$ & $\mathbf{2 . 5}$ & $\mathbf{1 3 6 . 7 5}$ & $\mathbf{3 3 . 9 1}$ \\
\hline
\end{tabular}

Table 3. Climatic data of the three selected sites in 2015.

\begin{tabular}{|c|c|c|c|c|c|}
\hline $\mathbf{N}$ & Compound & RT & RO1(Site 1) & RO2 (Site 2) & RO3 (Site3) \\
\hline 1 & P-xylene & 10.775 & - & 0.69 & 0.67 \\
\hline 2 & $\alpha$-pinene & 12.752 & 40.95 & 16.78 & 17.16 \\
\hline 3 & Camphene & 13.271 & 8.08 & 2.46 & 4.92 \\
\hline 4 & $\beta$-pinene & 14.179 & 1.34 & 0.67 & 1.09 \\
\hline 5 & Myrcene & 14.346 & - & 0.76 & 0.54 \\
\hline 6 & Delta -3-carene & 15.208 & - & 1.26 & \\
\hline 7 & P-cymene & 15.675 & 3.24 & 1.21 & 0.60 \\
\hline 8 & Limonene & 15.846 & 5.49 & 3.52 & 2.80 \\
\hline 9 & Eucalyptol & 16.025 & 1.30 & 11.88 & 13.88 \\
\hline 10 & Gamma-terpinene & 16.843 & 1.29 & 0.66 & 0.52 \\
\hline 11 & Terpinolene & 17.917 & - & 1.23 & 0.77 \\
\hline 12 & Linalol & 18.169 & 2.87 & 3.91 & 1.42 \\
\hline 13 & Cyclopentadiene & 19.319 & - & - & 0.54 \\
\hline 14 & Camphor & 20.252 & 11.24 & 19.26 & 36.72 \\
\hline 15 & Iso Borneol & 20.873 & 3.96 & 12.29 & 7.58 \\
\hline 16 & $\begin{array}{l}\text { Bicyclo }(3,1,1) \\
\text { heptan-3-one }\end{array}$ & 21.175 & - & 3.16 & - \\
\hline 17 & Carvomenthenol & 21.185 & 1.42 & - & 1.38 \\
\hline 18 & Alpha-terpineol & 21.601 & 1.38 & 1.68 & 1.46 \\
\hline 19 & $\begin{array}{c}\text { Bicyclo }(3,1,1) \text { hept- } \\
\text { 2-ene-2-ethanol }\end{array}$ & 21.957 & - & 0.92 & 1.34 \\
\hline 20 & Verbenone & 22.406 & 11.90 & 12.19 & 3.44 \\
\hline 21 & Urea, phenyl & 23.505 & - & 1.14 & - \\
\hline 22 & Aceticacid & 24.845 & - & 2.96 & - \\
\hline 23 & Bornylacetate & 24.855 & 2.64 & & 1.42 \\
\hline 24 & Beta-caryophyllene & 29.510 & 1.81 & 1.36 & 1.26 \\
\hline 25 & Alpha-Humulene & 30.575 & 1.10 & - & 0.48 \\
\hline
\end{tabular}

Table 4. Rosmarinus officinalis essential oils composition (from the three sites). 


\begin{tabular}{|ccc|}
\hline sites & water extract & ethyl acetate extract \\
\hline Site 1 & $81.63 \pm 0.16$ & $123.22 \pm 0.31$ \\
\hline Site 2 & $114.10 \pm 0.15$ & $167.91 \pm 0.35$ \\
\hline Site 3 & $58.26 \pm 0.31$ & $73.75 \pm 0.07$ \\
\hline
\end{tabular}

Table 5. Total phenolics in the two extracts of Rosmarinus officinalis (mg GAE /g Dry Weight) (see text).

\begin{tabular}{|lll|}
\hline sites & water extract & ethyl acetate extract \\
\hline Site 1 & $28.86 \pm 0.31$ & $66.2 \pm 0.19$ \\
\hline Site 2 & $28.78 \pm 0.02$ & $93.1 \pm 0.07$ \\
\hline Site 3 & $14.63 \pm 0.08$ & $83.32 \pm 0.07$ \\
\hline
\end{tabular}

Table 6. Total flavonoids in the two extracts of the two species (mg EQ/g Dry Weight) (see text).

\begin{tabular}{|l|c|c|c|c|c|c|}
\hline \multicolumn{1}{c}{$\begin{array}{c}\text { extract } \\
\text { compound }\end{array}$} & W1 & W2 & W3 & EA1 & EA2 & EA3 \\
\hline Gentisic Acid & 4.953 & 2.025 & 20.233 & & & \\
\hline Chlorogenic Acid & 135.152 & 31.174 & 97.451 & 6.339 & 3.084 & 0.323 \\
\hline 4-Hydroxy Benzoic Acid & 119.621 & 39.320 & 583.822 & & & \\
\hline Protocatechuic Acid & 14.246 & 16.941 & 12.645 & 1.011 & 1.402 & 0.510 \\
\hline Caffeic Acid & 11.867 & 160.719 & 87.937 & & & \\
\hline Vanilic Acid & & 14.015 & 26.788 & 0.934 & 1.529 & 0.515 \\
\hline Rutin & 7.889 & 2.471 & 24.260 & & & \\
\hline P-Coumaric Acid & & & 5.557 & & 1.461 & 0.134 \\
\hline Chcoric Acid & & & 11.582 & 1.225 & 1.173 & \\
\hline Ferulik Acid & 7.021 & 0.370 & 10.667 & & 3.509 & 0.498 \\
\hline Hesperidin & $\mathbf{8 9 6 3 . 1 1 4}$ & $\mathbf{5 4 1 2 . 5 8 7}$ & $\mathbf{1 4 6 7 9 . 3 0 6}$ & $\mathbf{6 1 1 . 0 3 1}$ & $\mathbf{3 4 8 . 1 6 8}$ & $\mathbf{6 0 . 9 0 0}$ \\
\hline Apigenin-7-Glucoside & & & & & & \\
\hline Rosmarinic Acid & $\mathbf{1 5 8 7 . 8 2 7}$ & $\mathbf{1 6 6 4 . 3 9 6}$ & $\mathbf{1 6 5 3 . 5 9 2}$ & $\mathbf{1 9 2 7 . 5 6 9 2}$ & $\mathbf{1 3 1 4 . 1 4 6}$ & $\mathbf{4 1 . 3 4 7}$ \\
\hline Salisilic Acid & & & 52.754 & & & \\
\hline Cinnamic Acid & 60.850 & & & 4.700 & & \\
\hline
\end{tabular}

Table 7. Phenolic compositions of Rosmarinus officinalis for the 3 sites. W: water extract, EA: EtOAc extract. Values are given as mg of phenolic compound per kg of dry weight of plant material.

to contain eucalyptol and camphor as the major compounds (Lakušić et al., 2012 ). Essential oils from 21 localities from Iran were found to contain variable percentages of major components such as: $\alpha$-Pinene (14.19-21.43\%), camphene (3.25$7.58 \%)$, 1.8-cineole (5.32-28.29\%), camphor (1.58-25.32\%), borneol (0.16-9.42\%), piperitone (4.21-7.71\%), and bornyl acetate (4.14-6.95\%) (Bajalan et al., 2017). The Tunisian rosemary from 4 geographic origins was reported to be rich in 1.8cineol (33.08-37.75\%), camphor (13.55-18.13\%), $\alpha$-pinene (8.58-9.32\%), $\alpha$-terpineol (6.79-8.17\%), camphene (5.07-5.58\%), borneol (4.08-5.48\%), limonene (3.19-3.04\%), and p-cymene (2.42$3.11 \%$ ) (Hcini et al., 2013).

\section{Total phenolics}

The content of the total phenolics is determined from a calibration curve of gallic acid taken as standard with a correlation coefficient $(\mathrm{y}=$ $0.0113 \mathrm{X}+0.0686, \mathrm{R} 2=0.9984)$.

The contents of total polyphenols are reported in micrograms of gallic acid equivalent per milligram of dry weight extract (mg GAE/g DW) in Table 5.

The results revealed important fluctuations in total phenolics. Site 2 (humid region) exhibits significant phenolic contents (114.10 and $167.91 \mathrm{mg}$ $\mathrm{GAE} / \mathrm{g} \mathrm{DW})$. This is certainly due to environmental factors, especially water and nutrients favorable 
for the biosynthesis of such elements. Site 3 , in turn displays less contents especially in water extracts (58.26 mg GAE/g DW).

\section{Flavonoids content}

The flavonoid content, expressed in microgram of quercetin equivalent per milligram of dry weight extract (mg QE/g DW), was determined from the regression curve whose equation is: $\mathrm{y}=0.0299 \mathrm{X}$ $+0.0979, \mathrm{R} 2=0.9746$.

The flavonoids contents seem to be less location-dependent for the case of water extracts in sites 1 and 2. However, in site 3 the plant displays only half of the other sites content (14.63 mg QE/g DW). Nonetheless, for ethyl acetate extracts, quite important oscillations were observed (66.2-93.1 $\mathrm{mg} \mathrm{QE} / \mathrm{g} \mathrm{DW}$ ) in site 3 (Table 6).

\section{High performance liquid chromatography analysis}

Recognition and quantification of phenolic compounds were carried out using analytical HPLC-TOF-MS and the results are shown in Table 7 expressed as mg of phenol per kg of dry weight of plant material.

Previous reports stated clearly the drastic dependence of these chemical contents with their geographic origins. For example, but not exclusively, the ethanol dry extract from Romanian Rosmarinus officinalis contains $3.22 \%$ of flavonoids (expressed as rutin equivalent), $34.30 \%$ phenol carboxylic acids (expressed as chlorogenic acid equivalent), 31.86\% total phenols (expressed as tannic acid equivalent), and 3.29\% rosmarinic acid (Gîrd et al., 2017). In Iran, the total phenolics were found to be $4.99 \pm 0.054 \mathrm{~g}$ of gallic acid equivalent $/ 100 \mathrm{~g}$ dry leaves instead of $4.99 \pm 0.054 \mathrm{~g}$ as gallic acid equivalent $/ 100 \mathrm{~g}$ dry leaves as reported by Tavassoli \& Emam Djomeh (2011).

\section{CONCLUSIONS}

The increased demand of natural products as substituent of synthetic drugs has rehabilitated concern in large-scale production. Environmental factors have impact on availability of active principles and affect remarkably the secondary metabolites contents in higher plants in medicinal plants, hence, therapeutic value also get influenced. It is well apparent that climate change, soil nature, aridity, and other factors considerably influence water availability, salinity, and several unfavorable circumstances having direct attitude on secondary metabolites yields and qualities. The present work, in the same context, highlights the effect of some abiotic aspects on essential oil and polyphenolic contents of Rosmarinus officinalis. Nevertheless, further studies are required to deepen the knowledge towards the establishment of a relationship leading to the use of such stresses as tools to increase the health-related properties of medicinal plant.

\section{ACKNOWLEDGMENTS}

The authors would like to deeply thank Pr. Ibrahim Demirtas and his research team for his warm welcome and research facilities during our stay in the Laboratory of Plant Research, Department of Chemistry, Uluyazi Campus, Cankiri Karatekin University, Cankiri, Turkey.

\section{REFERENCES}

AI-Sereiti M.R., Abu-Amerb K.M. \& Sena P., 1999. Pharmacology of rosemary (Rosmarinus officinalis Linn.) and its therapeutic potentials. Indian Journal of Experimental Biology, 37: 124-130.

Bajalan I., Rouzbahani R., Ghasemi Pirbalouti A. \& Maggi F., 2017. Quali-quantitative variation of essential oil from Iranian rosemary (Rosmarinus officinalis L.) accessions according to environmental factors. Journal of Essential Oil Research, 29: 16-24. DOI: 10.1080/10412905.2017.1380542

Borges L.L., Alves S.F., Sampaio B., Conceição E.C., Bara M.T.F. \& Paula J.R., 2013. Environmental factors affecting the concentration of phenolic compounds in Myrcia tomentosa leaves. Brazilian Journal of Pharmacognosy, 23: 230-238. DOI: 10.1590/ S0102-695X2013005000019

Boutekedjiret C., Bentahar F., Belabbes R. \& Bessiere J., 1998. The essential oil from Rosmarinus officinalis L. Journal of Essential Oil Research, 10: 680-682. DOI: 10.1080/10412905.1998.9701008

Chalchat J.C., Garry R.P., Michet A., Benjilali B. \& Chabart J., 1993. Essential oils of rosemary (Rosmarinus officinalis L.). The chemical composition of 
oils of various origins (Morocco, Spain, France). Journal of Essential Oil Research, 5: 613-618. http:// www.nal.usda.gov/

Gîrd C.E., Nencu I., Popescu M.L., Costea T., Duţu L.E., Balaci T.D. \& Olaru O.T., 2017. Chemical, Antioxidant and Toxicity Evaluation of Rosemary Leaves and its Dry Extract. Farmacia, 65: 978-983.

Gobbo-Neto L. \& Lopes N.P., 2007. Plantas medicinais: fatores de influência no conteúdo de metabólitos secundários. Quim Nova, 30: 374-381.

Guo L., Wang S., Zhang J., Yang G., Zhao M., Ma W., Zhang X., Li X., Han B., Chen N. \& Huang L., 2013. Effects of ecological factors on secondary metabolites and inorganic elements of Scutellaria baicalensis and analysis of geoherblism. Science China Life Sciences, 56: 1047-1056. DOI: 10.1007/s11427-013$4562-5$

Gurbuz B., Bagdat R.B., Uyanik M. \& Rezaeieh K.A.P., 2016. Rosemary (Rosmarinus officinalis L.) cultivation studies under Ankara ecological conditions. Industrial Crops and Products, 88: 12-16. DOI: 10. 1016/j.indcrop.2015.12.028

Hanif A., Juahir H., Lananan F., Kamarudin M.K.A, Adiana G., Azemin A. \& Ireana Yusra A.F., 2018. Spatial Variation of Melaleuca cajuputi Powell Essential Oils. Journal of Fundamental and Applied Sciences, 10: 139-155.

Hcini K., Sotomayor J.A., Jordan M.J. \& Bouzid. S. 2013. Chemical Composition of the essential Oil of Rosemary (Rosmarinus officinalis L.) of Tunisian Origin. Asian Journal of Chemistry, 25: 2601-2603. DOI: 10.14233/ajchem.2013.13506

Lakušić D.V., Ristić M.S., Slavkovska V.N., Šinžar Sekulić J.B. \& Lakušić B.S., 2012. Environment-related variations of the composition of the essential oils of rosemary (Rosmarinus officinalis L.) in the Balkan Penninsula. Chemistry \& Biodiversity, 9: 1286-1302. DOI: $10.1002 / \mathrm{cbdv} .201100427$

Pino J.A., Estarrón M. \& Fuentes V., 1998. Essential oil of rosemary (Rosmarinus officinalis L.) from Cuba.
Journal of Essential Oil Research, 10: 111-112. DOI: $10.1080 / 10412905.1998 .9700854$

Quettier D.C., Gressier B., Vasseur J., Dine T., Brunet C., Luyckx M.C., Cayin J.C., Bailleul F. \& Trotin F., 2000. Phenolic compounds and antioxidant activities of buckwheat (Fagopyrum esculentum Moench) hulls and flour. Journal of Ethnopharmacology, 72: 35-42.

Ramakrishna A. \& Ravishankar G.A., 2011. Influence of abiotic stress signals on secondary metabolites in plants. Plant Signaling \& Behavior, 6: 1720-1731. DOI: $10.4161 / \mathrm{psb} .6 .11 .17613$

Rhodes M.J.C., 1994. Physiological roles for secondary metabolites in plants: some progress, many outstanding problems. Plant Molecular Biology, 24: 1-20.

Rozman T. \& Jersek B., 2009. Antimicrobial activity of rosemary extracts (Rosmarinus officinalis L.) against different species of Listeria. Acta Agriculturae Slovenica, 93: 51-58. DOI: 10.2478/v10014009-0007-z

Singh M. \& Guleria N., 2013. Influence of harvesting stage and inorganic and organic fertilizers on yield and oil composition of rosemary (Rosmarinus officinalis L.) in a semi-arid tropical climate. Industrial Crops and Products, 42: 37-40.

Singleton V.L., Orthofer R. \& Lamuela-Raventos R.M., 1999. Analysis of total phenols and other oxidation substrates and antioxidants by means of FolinCiocalteu reagent. Methods in Enzymology, 299: 152-178. DOI.org/10.1016/S0076-6879(99)99017 $-1$

Tai J., Cheung S. \& Wu Mand Hasman D., 2012. Antiproliferation effect of rosemary (Rosmarinus officinalis L.) on human ovarian cancer cells in vitro. Phytomedicine, 19: 436-443. DOI: $10.1016 / \mathrm{j}$. phymed.2011.12.012

Tavassoli S. \& Emam D.Z., 2011. Total Phenols, Antioxidant Potential and Antimicrobial Activity of Methanol Extract of Rosemary (Rosmarinus officinalis L.). Global Veterinaria, 7: 337-341. 